супасимон товлар - возвышение, горное возвышение. Термин супатог означает сверху ровную или немного ребристую, срезаннную по бокам прямую отдельную гору, холм, возвышение.

В заключение можно сказать, что в оронимии Южного Узбекистана арабских оронимов не встречается. Можно видеть, что арабские слова существующие в составе оронимов свойственные речи местного населения, образованы согласно законам узбекско и персидско-таджикского языков.

\section{Литиратуры}

1. Андреев М. С. и Пещерова Е.М. Ягнабские тексты. М., - Л. Акад. Наук СССР, 1957. - 390 с.

2. Арабско-русский словарь. Сост. Х.К. Баранов. М., 1962.

3. Географик терминлар ва тушунчалар изохли луғати (тузувчилар: Қораев С., Ғуломов П., Рахимбеков Р.). Т., 1979.

4. Савина В.И. Орографическая терминология Ирана.// Оронимика (Сборник статей). М., 1969. стр. 54-58.

5. Сатторий Х. Амир Темур севган юрт. Тошкент: Ўзбекистон, 1996.

6. Шарафиддин Али Яздий. “Зафарнома”. Тошкент, 1997.

\title{
THE ROLE OF A CLASS TEACHER IN INCLUSIVE EDUCATION
}

İskenderova's A Yaşar convey candidate ped. nauka

\section{РОЛЬ КЛАССНОГО УЧИТЕЛЯ В ИНКЛЮЗИВНОМ ОБРАЗОВАНИИ}

\author{
DOI: $10.31618 /$ ESU.2413-9335.2019.7.62.135 \\ Искендерова Кенул Ячар гызы \\ кандидат пед. наук
}

\section{АННОТАЦИЯ}

Статья посвящена роли учителя в инклюзивном образовании, где обьясняются подход и отношение учителя, а также влияние созданных им условий.

\section{PEЗЮМЕ}

Инклюзивное образование -достаточно гибкая система. Она основана на том, что все дети разные, что они не должны отвечать жестким требованиям и стандартам, но при этом все могут учиться. Педагогические работники образовательного учреждения должны знать основы коррекционной педагогики и специальной психологии, иметь четкое представление об особенностях психофизического развития детей с ограниченными возможностями здоровья, о методиках и технологиях организации образовательного и реабилитационного процесса таких детей. Инклюзивное образование само по себе организовать невозможно. Этот процесс связан с изменениями на ценностном, нравственном уровне. Для развития инклюзивного подхода в общем образовании необходима разработка общепедагогических технологий, моделей развивающего урока, технологий поддержки и детского сотрудничества, вовлечения родителей в педагогический процесс.

\section{ABSTRACT.}

The article discusses the teacher's role in inclusive education, where approach, attitude, and conditions created by her is widely explained.

Key words: to formulate inclusion in society, inclusive education, specific learning difficulties.

Ключевые слова: формирование инклюзивного общества, инклюзивное образование, конкретные трудности в обучении.

\section{Introduction:}

Benefits of inclusive education include an opportunity for special-needs students to learn team works kills while heightening their sense of belonging in the school community. This article reviews some of the barriers to the development of successful inclusive education and suggests that one way of overcoming these difficulties is to reconsider the roles and responsibilities of parents and school teachers in inclusive education and also provides some suggestions to be acted out well.

Every child has the right to education. That includes children with disabilities. An inclusive education system is one that accommodates all students whatever their abilities or requirements, and at all levels pre-school, primary, secondary, tertiary, vocational and life-long learning. The two statements 'All children have an entitlement to education' and 'All children have the capacity to make progress' are easy ones to make and to secure agreement on. But while these fundamental beliefs are common, the building blocks that create our educational landscapes - policies, infrastructure, teaching practices, societal values and resources often mean that fully achieving such aspirations can be at best challenging and in the worst cases, almost impossible. Inclusion in society and education is affected by many factors, both externally from the environment and internally from our attitudes and beliefs. What happens in the classroom is just as important as what happens outside.

Current definitions of education 'quality' tend to focus on literacy and numeracy, and while this is important - both in itself and as a way to access other learning - it is a narrow definition of quality and fails to look at what education is for in a broader sense. If education is also about social justice and citizenship, a 
classroom practice that promotes gender equality is also critical, not least because the messages communicated in the classroom about what girls and boys can do and be is likely to have an impact on subject choice, progression and life chances. Inequalities between girls and boys affect their educational opportunities and outcomes at every level. While some issues such as lack of schools or poorly skilled teachers affect all children's learning in a given context, other barriers to education apply specifically to girls. Traditional expectations around girls' choices and behavior can determine whether they get access to the classroom in the first place, limit the time they have available for learning, and undermine the confidence they have in certain subjects and the degree to which they participate in lessons. Discriminatory gender norms also influence the perceived value of girls' education in those around them. This can ultimately shape and determine their future aspirations and opportunities. Turkey has a particular set of education challenges for girls. On the surface, gender parity has been achieved. (1) April 2019 is the 25th anniversary of the Salamanca Statement on Special Educational Needs Education published by UNESCO. Signed by 92 countries, the Salamanca Statement was recognized as a significant milestone in moving towards more inclusive education, providing a framework for how to make progress in terms of policy and practice. (5) The statement advocated that mainstream schools which adopt an inclusive approach are 'the most effective means of combatting discriminating attitudes, building an inclusive society and achieving education for all'. Inclusive education, the idea of all children being educated together in a unified educational system regardless of any differences between them, was originally concerned with the inclusion of learners with disabilities, many of whom had historically been excluded from mainstream schools. The study outlines the most important forms of support that are available to every school: children supporting children, teachers supporting teachers, parents becoming partners in the education of their children and communities supporting their local schools. The aspects of this support are described as: school leadership (supporting teachers to apply new knowledge and skills), continued professional learning for teachers (peer-to-peer learning), effective practice (differentiated teaching and learning) and developing an inclusive school culture (actively engaging children, parents and communities). The teacher needs assessment that every teacher needs to learn about various disabilities and how to best teach and support children with different disabilities with a positive approach. This can be achieved by embedding disability-inclusive pedagogy, child rights, equity and equality throughout all pre-service and in-service modules rather than simply covering these issues as standalone courses, while also establishing partnerships with community-based rehabilitation initiatives and disabled persons' organizations. As teachers we know that good communication is vital for successful learning, so it is not surprising that this is a worry for English language teachers across the world. Communication skills help children to understand and explain the world around them, share their ideas and feelings and make friends. Good language skills enable a child to reason and learn. They also help to develop a sense of self and the feeling of belonging to a group or community. If we discover that there is a learner with speech and language difficulties in our class, we might wonder how to help them to get the most from our lessons. By understanding the different kinds of speech and language impairment and knowing some useful teaching strategies we can really make a difference to these learners and help them to experience enjoyable and successful learning. Speech and language impairment varies from person to person and can range from mild to severe. A learner may have difficulty with speaking, 'expressive language' or understanding, 'receptive language'. They may have problems expressing feelings and interacting with others. This can cause low self-esteem and frustration, and may lead to behavior problems in the class. As speech and language problems are not always obvious, we have to think about what lies behind the behavior and the need the learner may be trying to express.

Most children with speech or language impairment are of average intelligence, but may have other specific learning difficulties such as dyslexia, dyspraxia or ADHD. Speech and language impairment is sometimes linked with conditions such as hearing loss, Down syndrome, cerebral palsy or autism. Chronic ear infections may also be a cause. Some learners have difficulty with both languages input and output and need to be taught the communication skills that other learners learn automatically. Some learners have problems with the muscular movements needed to form words. They may have trouble producing certain sounds and simply leave them out, or substitute one sound for another. This can make them difficult to understand and result in delayed or unclear speech.

Expressive language difficulties can also affect the ability to put words in the right order in a sentence and tell stories with the events in the right sequence. Their speech can be jumbled up and hard to understand. Sometimes the learner will use inappropriate grammatical structures and their speech may sound immature for their age. They may also have trouble with learning and accessing vocabulary. These problems occur in their own language and will also appear when learning English. Having trouble explaining and describing things makes it hard to join in class discussions. Some learners have problems with the way they hear and process language. This can impact on the ability to understand what others are saying and respond appropriately. Learners with hearing impairment have a physical barrier to understanding speech, but there are can also be 'pragmatic language' difficulties where, although the learner can hear what is being said, they do not understand the meaning. They may not know how to use social language and lack an intuitive understanding of social cues and conventions. There can also be problems understanding 'figurative language', which includes the use of irony, humour and metaphor. This can lead to a tendency to take things too literally. A learner with receptive language difficulties may have trouble in one or more of these areas.

Learning is a social process and learners can develop greater knowledge and skills when working with others than they can on their own. There is therefore an increasing appreciation and promotion of the use of paired and group work. Being a member of a class community requires the ability to listen, understand, speak 
clearly, respond appropriately, express thoughts coherently, play and work cooperatively and empathize. Learning in a social context presents challenges for pupils with problems in the area of communication and interaction. The range of difficulties is wide and includes pupils with speech and language difficulties, specific learning difficulties such as dyslexia and dyspraxia, hearing impairment, those who are on the autistic spectrum, and those with moderate, severe or profound learning difficulties. Brandon contends that overcoming speech, language and communication barriers to learning is recognized as crucial to enabling children to access the whole curriculum. Language and communication allow the learner to participate in various activities, for example, in cooperative learning groups and discussions. (2) Curriculum are valid for teaching students with disabilities. Nonetheless, language instruction to students with disabilities is more successful and effective when the following principles, which should be the basis of all teaching but which are especially important for teaching students with disabilities, are applied:

- Create a language-rich environment. dent.

-Adjust teaching to the individual pace of each stu-

- Offer success-oriented activities to the student.

- Plan instruction so as to include experiential activities.

- Break down the learning assignments into subtasks, in keeping with the student's needs.

- Vary activities within the lesson and from one lesson to another.

- Provide extensive drilling, memorization and repetition of the learning material.

- Include many visual and tactile aids, such as pictures and objects while teaching.

Students with disabilities commonly share learning difficulties, such as learning how to read and or write, processing information quickly and efficiently, as well as kinesthetic, emotional and social difficulties that can affect their learning. The assumption is that in spite of their difficulties in various learning domains comprehension, abstract thinking, memory, retrieval, attention and concentration, as well as motivation for learning - these students need to acquire knowledge and skills in the English language and are capable of doing so. Students with learning disabilities should be expected to meet the standards of the English Curriculum. They have been diagnosed by a psychologist or an educational specialist and their abilities and specific areas of disability have been identified. Recommendations for modifications and required instruction have been made. It is vital that the English teacher read the diagnosis and recommendations and apply them when teaching. It is strongly recommended that English teachers of students with learning disabilities, whether in an integrated or a separate class, receive appropriate training in order to be qualified to teach this student population. It is likewise recommended that the English teacher in a regular class consult with the special education teacher in the school or with another professional when designing the program of studies for this student population. These students require individual language programs. Language abilities must be assessed by a speech therapist. Teachers should be aware of difficulties that might arise in tasks requiring social interaction, such as role play, group or pair discussions and activities involving expression of feelings. Difficulties may arise when such students are required to establish eye contact with the speaker (the teacher or another student) and in assignments requiring oral presentation, identification of the writer's or reader's opinion, stance and emotions. However, in teaching English, the English teacher has to benefit from support: the parents', the supporting teacher's and even the school psychologist's. There are certain strategies that an English teacher has to take into account. For instance, the lesson should be planned according to the following criteria:

- the teaching material should be catchy and attractive

- the teacher should plan extra working time with the child

- the teacher along with the inclusive education specialist should draw up an individual study plan

- The atmosphere should be pleasant as children feel uncomfortable working under pressure, in stressful situations or in a boring activity.

Foreign language teachers who work in an inclusive classroom may have additional problems due to insufficient training and qualifications in working with exceptional children. The teachers also need to be openminded towards working in inclusive classrooms, and willing to adapt teaching materials and methods to meet the needs of students with disabilities or difficulties. Teachers who teach students with foreign language learning difficulties are faced with numerous challenges. Ganschow and Schneider state that training and education for foreign language teachers usually prepares them for the "ideal learner" who is expected to master language skills (pronunciation, reading, writing, speaking and listening) through exposure and practice. (3) They point out the need for additional training in meeting the needs of students with special needs. Foreign language teachers should learn to determine the most beneficial accommodations for their students, and to identify students at risk of developing a foreign language learning disability as early as possible. Classroom conversations, discussions and the medium of instruction used in teaching and learning do not exclude learners in special needs receiving their education in special or inclusive schools. Sometimes it may be difficult for teachers and nondisabled learners to interact with learners in special needs due to the fact that the latter might feel uncomfortable or be neglected by their teachers and fellow learners. At times they may not be able to participate in classroom conversations due to their being handicapped through language. Collaborative partnerships must be built with the family supporting a student with disability to maximize opportunities and learning outcomes for the student. It is important to develop respectful relations with students and their families to foster an appreciative view of the student's strengths, needs and interests and promote an atmosphere of mutual respect. Students have differing social and emotional strengths, rates and styles of learning, talents and capacities. Rather than focusing on just their disability, consider what are the qualities that make the 
student with disability an individual person. The student's family will have a wealth of knowledge about the child and the disability. Effective teachers build students' skills to work cooperatively and with greater responsibility and independence for their own learning. They create learning tasks that are grounded in year level curriculum and activate or scaffold for background experiences in ways that are engaging and support growth.

A student has great difficulty with handwriting due to poor fine motor control. She is encouraged to practice and develop her handwriting skills at specific times. However, when the focus is on her understanding, knowledge or creativity she types or uses speech to text technology for her responses. This allows free-flow of all of her thoughts and understanding to be shared, without being impacted by her motor capability. trainee teachers and experienced teachers need to learn about the concept of inclusive education, but then also need plenty of opportunities to both observe and implement the theories in practice, ideally with support from experienced colleagues or mentors. They need to be facilitated to reflect on how their practices relate to educational theory, and how they can turn theoretically good ideas into sound practice. Practice-based teacher training needs to be relevant to the local context and culture, and needs to be a well-managed process so that teachers'/trainee teachers are not overwhelmed. The split between theory and practice needs to be well-balanced. Too much theoretical and too little practice-based learning can leave teachers ill-prepared for the real-life challenges they will face in class. Equally, however, if there is very little theory-based learning, teachers can miss out on vital opportunities to learn from wider sources of information, and to learn how to be more re- flective and analytical practitioners. Teachers have direct interaction with students and play a critical role in determining students' experiences in the classroom on a daily basis. Special attention must be paid to ensure that classroom teachers have the skills and support needed to provide quality education to children with diverse learning needs. This requires the collaboration of classroom teachers, key teachers, school principals, education officers and policy makers. It is often argued that a lack of knowledge on the part of classroom teachers, attribute to a lack of training, is the main barriers to inclusion. Inclusion involves the use of support, the ways in which teachers respond to individual differences during whole class teaching, the choices they make about group work and they utilize specialist knowledge. (4) the teaching material should be catchy a $\quad$ the curriculum

\section{Список литературы}

1. MEB (2015) National Education Statistics:

Formal Education 2014/2015.

2. Brandon, D.P. 2006. Botswana's family and consumer sciences teachers' attitudes towards the inclusion of students with physical disability. Journal of Family and consumer sciences education, 24 (1): 3749.

3. (Ganschow, L. \& Schneider, E. (2006). Assisting Students with Foreign Language Learning Difficulties in School. Retrieved October 2016. from http://www.ldonline.org/article/22725/)

4. Florian, L., "Special or Inclusive Education: Future Trends". British Journal of special education, Vol. 4, 2008, pp: 202- 208.

5. www.unesco.org/new/en/media-services/single view/news/a_guide_for_ensuring_inclusion_and_equity_in_education/

\title{
НАЦИОНАЛЬНО-КУЛЬТУРНЫЕ ОСОБЕННОСТИ РУССКОГО И АНГЛИЙСКОГО КОММУНИКАТИВНОГО ПОВЕДЕНИЯ
}

\author{
Керимова Ксения Расимовна \\ Студент магистратуры 1 курс, направление «Лингвистика», \\ Сургутский государственный университет, г. Сургут \\ Научный руководитель: Коптякова Е.E., \\ к.ф.н., доцент, Сургутский государственный университет, г. Сургут
}

\begin{abstract}
АННОТАЦИЯ.
Данная статья посвящена сопоставлению национально-культурных особенностей коммуникативного поведения.

Цель работы - выявить черты сходства и различия коммуникативного поведения русских и англичан, представить их на основе наиболее ярких ситуативных примеров.

Результатом проделанной работы является сопоставительный анализ доминантных особенностей вербальной коммуникации у представителей русско- и англоязычного лингвокультурных сообществ.

\section{ABSTRACT.}

This article is dedicated to the comparison of national-cultural peculiarities of communicative behavior. The scientific purpose of the work is to identify the similarities and differences in the communicative behavior of Russians and Englishmen and to give bright examples. The result of the article is a comparative analysis of the dominant features of verbal communication among representatives of Russian and English linguocultural communities.
\end{abstract}

Ключевые слова: коммуникативное поведение, вербальная коммуникация, нормативное коммуникативное поведение, коммуникативная категория.

Key words: communicative behavior, verbal communication, standardized communicative behavior, communicative category. 